\title{
UNIVERSALITAS MAHATMA GANDHI
}

\author{
Oleh \\ I Made Arsa Wiguna \\ Dosen pada Jurusan Pendidikan Agama IHDN Denpasar
}

\begin{abstract}
ABSTRAK
Penelitian ini bertujuan untuk menyampaikan gagasan tentang pemikiran universal MK Gandhi atau yang lebih dikenal dengan Mahatma Gandhi.Beliau adalah sosok yang rendah hati namun memiliki pemikiran yang sangat dalam tentang kehidupan. Beliau juga merupakan tokoh paling penting dalam kemerdekaan India. Empat ciri khas Mahatma Gandhi dalam usahanya merebut kemerdekaan India yakni Ahimsa, Satyagraha, Swadesi, dan Hartal. Semangat dan prinsipprinsip universal inilah yang hendaknya diwarisi dan dikorelasikan dengan kehidupan saat ini.
\end{abstract}

\section{Kata Kunci : Universalitas, Mahatma Gandhi}

\section{ABSTRACT}

This paper aims to convey the idea of MK Gandhi universaity thought. MK Gandhi or well known as Mahatma Gandhi is a humble figure but has a deeply thought about life. He is also the most important figure in the Indian independence. Four characteristic of Mahatma Gandhi in his bid for the independence of India is Ahimsa, Satyagraha, Swadesi, and Hartal. The spirit and the universal principles that should be inherited and correlated with the current life.

\section{Keywords : Universality, Mahatma Gandhi}

\section{PENDAHULUAN}

Sosok dan ajaran Mahatma Gandhi telah membawa perubahan besar bagi peradaban India bahkan dunia sekalipun. Perjuangannya yang tiada henti memerangi segala bentuk penindasan dan kekerasan merupakan prinsipprinsip utama yang ia tanamkan. Penderitaan yang timbul sebagai akibat konflik dan peperangan yang terjadi telah mengusik hati nuraninya dan membangkitkan semangat anti kekerasan dalam dirinya. Terlahir dengan nama Mohandas Karamchand Gandhi, pada 2 Oktober 1869, Mahatma Gandhi tumbuh menjadi sosok humanis yang mengedepankan sisi kemanusian dan kebenaran dalam setiap usaha perdamaiannya. Gandhi terlahir dalam keluarga terpandang dan penganut agama Hindu yang taat dan tradisi keagamaan yang ketat. Ayahnya bernama Karamchand Gandhi merupakan seorang anggota Pengadilan Rajasthanik yang sangat disegani dan sangat berpengaruh dalam menyelesaikan perselisihan antara para pemuka dengan kaum kerabatnya pada masa itu. Ibunya, Putlibai adalah penganut Hindu yang taat, beliau sering melakukan brata yang ketat dan tidak pernah menyimpang sedikitpun. Beliau tidak akan makan sebelum melakukan persembahan dan puja sehari-hari. Mengunjungi Haveli-kuil Vaisnawa merupakan salah satu kewajibannya sehari-hari, dan beliau juga sangat ketat dalam berpuasa setiap Caturmasa tiba (Gandhi dalam Wisarja, 2007: 28).

Sejak kecil, Gandhi sudah memegang teguh bhakti dan kejujuran yang kemudian menjadi cita-citanya. Gandhi menikah di usia yang sangat muda yakni pada usia 13 tahun dengan Kasturbai akibat perjodohan oleh 
orangtuanya. Gandhi menekuni ilmu hukum di London, dan menyelesaikan studinya pada tahun 1891 dan memulai karirnya pada tahun 1893 di Afrika Selatan. Kedatangan Gandhi di Afrika Selatan merupakan titik awal perubahan dalam hidupnya. Ketika ia datang, Afrika Selatan tengah diguncang konflik antar ras kulit hitam dan kulit putih. Louis Fischer (dalam Wisarja, 2007: 34) menyatakan bahwa perjuangan dan pengalaman Gandhi di Afrika Selatan memunculkan sebuah gagasan yang ia cetuskan yakni Satyagraha yang berarti kekuatan kebenaran atau kekuatan kasih sayang. Satyagraha merupakan usaha untuk mempertahankan kebenaran bukan dengan hukuman yang menderitakan lawan, namun dengan hukuman terhadap diri sendiri agar tercipta hubungan yang positif antara lawan dengan tujuan perdamaian yang sesungguhnya.

Ada empat hal mendasar yang menjadi ciri khas Gandhi pada masa perjuangannya meraih kemerdekaan di India yakni: 1) Ahimsa yang tidak hanya diartikan sebagai perbuatan tidak menyakiti sesama, namun lebih kepada sikap menolak keinginan untuk membunuh, tidak membahayakan jiwa, tidak menyakiti hati, tidak membenci, tidak membuat marah, tidak mencari keuntungan sendiri dengan memperalat orang lain, dan sejenisnya; 2) Satyagraha yang berarti memegang teguh kebenaran dengan tidak mengenal lelah, serta jalan untuk mencapai satyagraha adalah dengan mempraktikkan ahimsa; 3) Swadesi sebagai bentuk rasa cinta terhadap tanah air, serta mengabdi kepada masyarakat yang sebaik-baiknya terlebih dahulu; dan 4) Hartal adalah semacam pemogokan nasional yang dilakukan dengan berpuasa serta melakukan kegiatan keagamaan.

Selain ajaran tentang humanisme dalam kehidupan sosialnya, prinsipprinsip religiusitas Gandhi tentu tidak dapat dikesampingkan. Wisarja (2007: 70) menguraikan bahwa pemikiran-pemikiran Gandhi dalam bidang kemanusiaan, keagamaan, dan sosial politik (meskipun tidak dikehendakinya), seperti misalnya memintal menuju kemenangan, pembangkangan sipil, sejumput garam, perlawanan pasif satyagraha, ahimsa, swadesi, hartal, persamaan hak antara kaum berkasta dengan kaum paria, dan lain sebagainya, telah banyak mempengaruhi serta menyiapkan rakyat India untuk menuju kemerdekaan, dan akhirnya rakyat India mencapai kemerdekaannya pada tanggal 15 Agustus 1947.

Sebagai penganut Hindu yang taat, Gandhi mencerna ajaran dalam Bhagavadgita dan mengadopsi serta mengaplikasikannya ke dalam prinsip-prinsip keagamaannya yakni: 1) Samakhava yang berarti seseorang tidak boleh merasa terganggu karena perasaan sakit atau senang; 2) Aparigraha yaitu sikap tak memiliki terhadap kebendaan, dan 3) Ahimsa yaitu tidak menyakiti segala yang bernyawa, nir kekerasan (Nicholson dalam Wisarja, 2007: 70,71). Lebih lanjut disampaikan bahwa selama berada di Afrika Selatan dan India, Gandhi mendapat pengaruh besar dari agama dan filsafat lainnya. Gandhi mencintai ajaran Kristus, kotbah Kristus di gunung seperti "berbahagialah mereka yang lemah...", "berbahagialah mereka yang miskin, bagimu adalah Kerajaan Tuhan...", "kasihilah musuhmu...", " jangan mengumpulkan harta benda di bumi bagi dirimu sendiri...". Ajaran Kristus itu meresap dalam nurani Gandhi, dan ia juga tidak menolak pandangan agamaagama besar lainnya seperti Buddha, Jaina, Islam. Universalitas Gandhi itulah yang akhirnya membuat ia terbunuh oleh seorang Hindu fanatik akibat usahanya membantu umat Muslim. Meskipun demikian, Gandhi tidak mengesampingkan agama yang dianutnya. Ia adalah penganut Hindu yang taat, mengingat pengaruh ibunya yang sangat taat dalam menjalankan bhakti dan brata. Ia juga mempelajari bahasa Sanskrta serta menghafal Gita dan terlebih meninggalkan keduniawian sehingga menjadi Mahatma (berjiwa besar). Gandhi memahami Tuhan 
dalam wujud universal. Gandhi memiliki prinsip bahwa kebenaran adalah Tuhan, kebenaran adalah satu-satunya sebutan untuk Tuhan yang tepat dan sarat arti. Dimana ada kebenaran disitu ada pengetahuan yang benar, dan dimana tak ada kebenaran disitu tak mungkin ada pengetahuan yang benar (sejati), maka dari itu Tuhan dikenal sebagai Sat Chit Ananda, Dia yang mencakup dalam diri-Nya Kebenaran, Pengetahuan dan kebahagiaan sejati (Prabhu, 1996: 5). Lebih lanjut akan dibahas pandangan universal Gandhi terhadap agama-agama yang ada.

\section{PEMBAHASAN}

Kebenaran adalah Tuhan, dan bukan sebagaimana lazimnya Tuhan adalah Kebenaran, demikian pandangan Gandhi terhadap Kebenaran yang membuatnya mampu melihat Tuhan seakan-akan berhadapan langsung dengan-Nya. Kebenaran itu harus mencakup kebenaran dalam pikiran, perkataan, dan perbuatan. Untuk menemukan kebenaran sebagai Tuhan, maka satu-satunya jalan yang tak dapat dihindari adalah kasih sayang, yakni emoh kekerasan (ahimsa). Ahimsa menurut pandangan Gandhi tidak terbatas pada sikap saja, melainkan mencakup pikiran, perkataan dan perbuatan, yang tidak hanya ditujukan kepada manusia saja, melainkan juga kepada binatang dan tumbuhtumbuhan. Menurut pandangan Gandhi, Tuhan itu bersegi banyak, dan baginya Tuhan itu tidak sama untuk setiap orang. Secara jelas ia mengatakan bahwa Tuhan itu kebenaran dan kasih. Tuhan itu etika dan moralitas, ketidaktakutan, sumber kehidupan sekaligus kesadaran.

Seperti yang dikutip dari kumpulan tulisan dan pidato Gandhi yang dihimpun Prabhu (1996: 15), Gandhi menyatakan bahwa Ahimsa adalah Tuhanku, dan Kebenaran adalah Tuhanku. Bila aku mencari Ahimsa, Kebenaran berkata "Temukanlah Itu melalui Ku”. Bila aku mencari Kebenaran, Ahimsa berkata "Temukanlah Itu melalui Ku". Lebih lanjut Gandhi menyatakan bahwa apa yang tampak sebagai kebenaran bagi seseorang, terlihat sebagai ketidakbenaran bagi orang lain. Namun hal itu tidak perlu dikhawatirkan bagi pencari kebenaran. Dimana ada ikhtiar yang jujur, disitu akan dihayati bahwa apa yang tampak sebagai kebenaran-kebenaraan yang berbeda, pada hakikatnya seperti daun-daun yang tak terhitung jumlahnya yang tampak jelas berbeda, tetapi pohonnya satu. Tuhan menampakkan diri pada setiap orang dengan wajah yang berbeda, namun Tuhan adalah Esa, maka tidaklah salah bagi setiap orang untuk mengikuti kebenaran sesuai dengan penglihatannya. Bila terdapat kesalahan dalam perjalanannya mengikuti kebenaran, maka dengan sendirinya dia akan dialihkan pada kebenaran. Atas dasar pemikiran itulah, muncul pandangan universal Gandhi terhadap ajaran-ajaran agama yang ada.

Agama-agama menurut pandangan Gandhi adalah berbagai jalan yang pada akhirnya bertemu pada satu titik yang sama, dan tidak ada yang patut dipermasalahkan jika mengambil jalan yang berbeda dengan tujuan yang sama. Semua agama adalah anugrah Tuhan, namun karena sifat manusia yang tidak sempurna, maka pemahaman terhadap agama menjadi berbeda. Durkheim (dalam Koentjaraningrat, 2005: 201-202) merinci unsur-unsur dasar religi yang akhirnya menimbulkan perbedaan dalam penafasiran agama dan ajaran-ajarannya yakni: 1) emosi keagamaan (getaran jiwa) yang menyebabkan manusia didorong untuk berprilaku keagamaan, 2) Sistem kepercayaan atau bayangan-bayangan manusia tentang bentuk dunia, alam, alam gaib, hidup, maut, dan sebagainya, 3) sistem ritus dan upacara keagamaan yang bertujuan mencari hubungan dengan dunia gaib berdasarkan sistem kepercayaan tersebut, 4) kelompok keagamaan atau kesatuankesatuan sosial yang mengkonsepsikan dan mengaktifkan religi berikut sistem upacaraupacara keagamaannya, dan 5) alat-alat fisik 
yang digunakan dalam ritus dan upacara keagamaan. Pandangan setiap orang terhadap agama tentu akan berbeda, dan setiap orang memiliki kebenaran dari sudut pandang mereka sendiri. Hal itu tidak menutup kemungkinan yang dianggap benar oleh seseorang atau sekelompok orang, bisa saja tidak benar atau salah. Atas dasar itulah diperlukan adanya toleransi yang lebih mengedepankan akal sehat dan kasih sayang yang sejati. Dengan semangat toleransi akan menghindarkan kita dari fanatisme berlebih dan memberikan kita pandangan rohani yang lebih mendalam. Pengetahuan yang benar tentang agama akan meruntuhkan dinding-dinding pemisah antara agama yang satu dengan yang lain dan sekaligus memupuk toleransi. Pemupukan toleransi terhadap agama lain akan memberikan kita pemahaman yang lebih mendalam tentang agama kita sendiri.

Hal itu ditunjukkan Gandhi ketika ia bertugas di Afrika Selatan. Perjumpaanya dengan orang-orang Kristen dan usahanya yang sungguh-sungguh untuk menghormati agama mereka membuat ia semakin yakin dengan keyakinan agamanya sendiri, agama Hindu. Ia sering mengikuti kebaktian pada beberapa gereja, dan bertemu dengan penganut Kristen yang menginginkan Gandhi memeluk agama Kristen. Dalam sebuah percakapan antara Gandhi dan Millie Polak, seorang Kristen yang menjadi murid pertama Gandhi di Afrika Selatan, ia menjelaskan alasannya mengapa ia tidak memeluk agama Kristen. Figur Yesus yang lembut, begitu sabar, begitu baik, begitu kasih, begitu pemaaf sehingga ia mengajarkan para pengikutnya untuk tidak membalas ketika dihina atau dipukul, tapi untuk memberikan pipi yang lain. Gandhi beranggapan bahwa inilah contoh yang indah dari orang yang sempurna (Madrasuta, 2002: 35). Gandhi menambahkan bahwa ia mempelajari kitab suci Kristen, namun ia sampai pada kesimpulan bahwa tidak ada sesuatupun yang terdapat dalam kitab suci Kristen yang tidak terdapat dalam kitab suci Hindu, dan untuk menjadi seorang Hindu yang baik, itu berarti ia juga harus menjadi seorang Kristen yang baik, namun itu tidak berarti ia harus ikut dalam keyakinan agama Kristen untuk percaya pada keindahan dari ajaran-ajaran Yesus atau untuk mencoba mengikuti teladannya. Bila seorang mencapai hati dari agamanya sendiri, ia telah mencapai hati dari agama-agama lainnya juga. Hanya ada satu Tuhan, tapi ada banyak jalan untuk menuju kepada-Nya (Madrasuta, 2002: 36).

Agama adalah tanggung jawab moral antara manusia dengan Sang Penciptanya. Gandhi menjelaskan bahwa semua agama menyebutkan Tuhan itu Esa, jadi jika teori ini diikuti maka akan hanya ada satu agama saja di dunia. Namun pada kenyataannya, banyak perbedaan yang muncul mengenai konsepsi tentang Tuhan. Allahnya Islam sama dengan Tuhannya orang-orang Kristen dan Ishwaranya orang-orang Hindu. Ada banyak nama Tuhan dalam Hindu, begitu pula dalam Islam. Sebutan-sebutan itu tidak menunjukkan pribadi-Nya tetapi hanya sifat-sifat-Nya, dan manusia kerdil telah mencoba dengan memberi-Nya sifat-sifat, walaupun Dia di atas semua sifat itu, karena Dia tak terlukiskan, di luar jangkauan fikiran dan tak bisa diukur (Prabhu, 1996: 43). Keyakinan itu terus berkembang hingga muncul tempat-tempat pemujaan atau tempat ibadah untuk lebih memusatkan perhatian umat kepada Tuhan. Tempat ibadah untuk umum bagaimanapun bentuknya agaknya merupakan suatu kebutuhan mendasar atau naluri bagi hati manusia. Berisi atau tidaknya patung dalam tempat ibadah adalah masalah temperamen dan selera. Tempat ibadah Hindu atau Katolik Roma yang berisi patung, bagi Gandhi tidaklah jelek atau bersifat tahayul, sedangkan Masjid atau Gereja Protestan dianggap baik atau bebas dari tahayul hanya karena tidak ada patung di dalamnya. Pada dasarnya semua tempat ibadah itu adalah baik. Iman menjadikan tempat ibadah tersebut sebagai tempat suci. Tempat itu merupakan jawaban 
terhadap kerinduan manusia untuk menggapai yang tak terlihat kasat mata. Ketika memasuki pura dengan iman dan rasa hormat, kita akan tahu bahwa setiap kali mengunjunginya, kita akan meninggalkannya dengan rasa telah disucikan, dan iman kitpaun semakin teguh percaya pada Tuhan yang tak dapat diingkari keberadaan-Nya. Bahkan pengalaman pahit telah megajarkan Gandhi bahwa tidak semua pura itu adalah tempat Tuhan bersemayam. Pura bisa juga menjadi tempat tinggal setan. Tempat-tempat peribadatan itu tidak memiliki nilai, kecuali penjaganya adalah hamba Tuhan yang baik. Manusialah yang menjadikan baik buruknya semua pura, masjid, dan gereja (Gandhi dalam Prabhu, 1996: 53)

Pandangan-pandangan Gandhi kemudian meluas hingga pada konsepsi tentang inkarnasi (penitisan) Tuhan. Dalam agama Hindu, Tuhan berinkarnasi (berawatara) menjelma menjadi penyelamat dunia dari belenggu adharma. Salah satu awatara Tuhan dalam manifestasi-Nya sebagai Dewa Wisnu adalah Krishna. Gandhi tidak yakin apakah Krishna dalam Mahabharata sungguh pernah hidup. Gandhi beriman kepada Krishna menurut imajinasinya yang merupakan seorang inkarnasi sempurna, tak tercela sedikitpun, pemberi inspirasi kepada Gita, serta pada kehidupan berjuta-juta umat manusia. Baik Rama maupun Krishna, dan lainnya disebut awatara atau inkarnasi Tuhan karena kita menganggap mereka memiliki sifat-sifat dewa. Sebenarnya mereka adalah ciptaan imajinasi manusia. Apakah mereka pernah hidup atau tidak, itu tidak mempengaruhi gambaran mereka dalam pikiran manusia. yang jelas bahwa Tuhan adalah kekuatan, Dia adalah zat hidup, Dia adalah kesadaran murni dan tak ternoda. Dia kekal, namun tak semua orang dapat memperoleh manfaat dari-Nya (Gandhi dalam Prabhu, 1996: 55, 56).

Gandhi memiliki sikap yang sama terhadap keyakian lain khususnya Buddha dan Islam. Penghormatan atas semua yang ia anggap sebagai kebenaran milik bersama, dan kritik terhadap semua bentuk ungkapan ketidak toleranan dan fanatisme. Dia percaya bahwa semua agama pada intinya benar, semuanya adalah jalan untuk menuju kebenaran yang sama. Demikian pula halnya semua agama tidak sempurna, dapat melakukan kesalahan dan perlu dimurnikan. Agama Hindu pun tidak lepas dari ketidaksempurnaan itu, seperti penindasan terhadap kaum Candala yang diangapnya sebagai penyimpangan terkutuk darikebenaranagama. Perjuangannya terhadap masalah toleransi agama dan komitmennya untuk mendamaikan perbedaan-perbedaan keyakinan ini yang telah merenggut nyawanya. Ia dibunuh oleh seorang ekstrimis Hindu yang merasa dikhianati karena perhatian dan keprihatinan Gandhi terhadap kesejahteraan orang-orang Muslim (Madrasuta, 2002: 11-12). Lebih lanjut disampaikan bahwa penghormatannya yang sama terhadap semua agama muncul dari satu konteks (lingkungan) India yang jelas, di Gujarat, orang-orang sekte Vaisnawa dan orang-orang Jain hidup berdampingan.

Toleransi, penghormatan yang sama terhadap semua agama, bukan berarti kita mengambil agama lain sebagai agama kita, tapi itu berarti mengjarkan kita untuk memahami sudut pandang mereka, untuk menghargai cahaya kemana mereka melihat di dalam agama mereka. Gandhi memaparkan bahwa satu penghargaan yang sederajat (equal regard) terhadap semua agama tidak berarti sinkretisme (percampuran) agama-agama. Gandhi tidak menghendaki percampuran itu, karena tidak akan ada penghargaan kepada agama yang lain jika semua agama dicampur jadi satu, hal ini malahan akan menghilangkan identitas yang lain (Madrasuta, 2002: 104). Pernyataan orang-orang dari berbagai tradisi keagamaan yang mengatakan bahwa kitab suci mereka adalah merupakan wahyu Tuhan digantikan oleh Gandhi sebagai pernyataan "diinspirasi oleh yang suci". Hendaknya kita menggunakan akal sehat untuk memahami apa arti kata kitab suci itu bagi kita. Jika hukum 
Manu (Manava Dharmasastra) menuntut penundukkan wanita atas pria, maka menurut Gandhi dalam hal ini Hukum Manu itu keliru. Bentuk penghormatan Gandhi terhadap agama-agama adalah studinya yang mendalam tentang kitab-kitab suci agama-agama yang ada. Dia sangat tertarik untuk mengetahui apa arti Perjanjian Baru bagi orang Kristen, dan ia dengan tegas mengatakan bahwa maknanya tidak hanya sebatas kepada orang Kristen saja, tapi juga memberi makna bagi dirinya sebagai seorang Hindu.

Namun di sisi lain, Gandhi juga memberikan pandangan bahwa semua agama tidaklah sempurna. Menurutnya, semua agama terdiri dari wahyu tentang Kebenaran, tapi semuanya tidak sempurna dan menjadi subjek kesalahan. Penghormatan terhadap agama-agama lain tidaklah harus membuat kita buta terhadap kesalahan-kesalahannya (Madrasuta, 2002: 105). Lebih lanjut menurut Gandhi, agama bukanlah "Kebenaran" meskipun agama mengajarkan kita untuk menuju Kebenaran. Agama adalah jalan hidup, pedoman untuk menemukan Kebenaran, namun sepanjang perjalanannya, semua agama mengalami penyimpangan, masa-masa gelapnya, fanatisme, dan kekejamannya. Diperlukan upaya untuk menyelami agamaagama lain guna mengetahui hal apa yan baik dari agama kita dan apa yang tidak baik dari agama lainnya. Pandangan-pandangan penganut agama terhadap agama lainnya sering menimbulkan perseteruan, karena perbedaan konsepsi tentang Kebenaran yang diyakini. Pengalaman Gandhi sewaktu muda ketika mendengar pernyataan-pernyataan tidak menyenangkan dari kaum missionaris Kristen terhadap Hindu yang mengatakan bahwa Hindu pemuja patung dan penganut paham politheis memberikan kita gambaran bahwa pandangan mereka terhadap Hindu adalah dari sudut pandang Kebenaran mereka. Demikian pula halnya ketika Gandhi mendengar pandangan terhadap Kristen dengan sebutan "beef and beer" karena kebiasaan mereka meminum alkohol dan makan daging sapi, dianggap suatu hal yang menjijikkan oleh orang-orang Hindu. Namun hal itu tidak membuat Gandhi berniat untuk membalas pandangan-pandangan tersebut, justru ia mendalami kitab suci Kristen, Injil. Dia mengakui bahwa dia menemukan bagianbagian Injil yang sangat membosankan dan bertentangan dengan akal sehatnya, tapi ia menemukan Injil juga memberinya pengaruh yang sangat dalam.

Gandhi selalu menekankan kepada setiap pria maupun wanita berbudaya untuk membaca secara simpatik kitab-kitab suci dunia, jika ingin menghormati agamaagama lain. Toleransi antar umat beragama tidak semata-mata menerima keberadaan mereka, namun juga mengetahui ajaran mereka, membandingkan dengan ajaran dalam agama kita, tidak untuk menimbulkan konflik, namun dengan toleransi itu akan meningkatkan keyakinan kepada ajaran agama kita. Seperti yang telah dialami Gandhi semasa di Afrika Selatan, dimana orangorang di sekitarnya menginginkannya untuk memeluk agama Kristen, tapi Gandhi tetap yakin akan ajaran agamanya Hindu, meskipun ia telah mempelajari kitab suci Kristen dan ia mengagumi ajaran-ajaran Yesus Kristus dan mengambil teladan dari ajaran tersebut.

Gandhi menyatakan bahwa diperlukan suatu studi yang ramah terhadap agama-agama dunia, bukan studi kritis terhadap mereka. Studi yang ramah itu bertujuan untuk memahami tradisi lain dari sudut pandang mereka yang melihatnya memberikan pemeliharan hidup dan menantang. Studi ini bagi Gandhi sendiri yang beragama Hindu didasari oleh pertanyaan mengapa tradisi Islam dan Kristen dapat dijadikan pedoman hidup yang mendasari kasih sayang dari sekian juta manusia selama berabad-abad. Tentu ada kebenaran di balik tradisi itu, hanya saja jika dilihat dari sudut pandang yang berbeda, maka yang dilihat mungkin saja hanya kesalahan dari tradis-tradisi 
tersebut. Perbedaan sudut pandang dapat menimbulkan konflik, dengan menemukan kesalahan-kesalahan pada orang lain, bahkan menistakan yang lain akan menghambat pemikiran universal terhadap kebenaran maupun keindahan yang nyata dari yang lain tersebut. Penekanan dalam studi ini yakni kita dianjurkan untuk mempelajarai tradisi-tradisi lain melalui tulisan-tulisan pemeluk yang teguh dari agama masing-masing. Gandhi mencontohkan, misalnya ketika kita ingin mempelajari Bhagawad Gita, kita tidak boleh membacanya melalui terjemahan yang dibuat oleh seorang pengeritik yang marah, tapi melalui terjemahan yang dibuat oleh seorang pencinta Bhagawad Gita. Studi bersahabat ini tidak berarti bahwa kita mengungkapkan mereka "semua sama saja". Tidaklah benar demikian, karena agama-agama itu berbeda layaknya kebudayaan-kebudayaan. Memahami partikularitas dari perbedaanperbedaan dari setiap tradisi yang ada sama pentingnya dengan memahami persamaanpersamaan mereka (Madrasuta, 2002: 112).

Pernyataan lainnya yang cukup menarik dari Gandhi yakni “ Pengembangan toleransi kepada agama-agama lain akan memberikan kita pengertian yang lebih benar tentang agama kita". Banyak orang yang beranggapan bahwa penghormatan dan penghargaan terhadap tradisi-tradisi lain akan menggoyahkan, bahkan melenyapkan keyakinan kepada agama sendiri. Gandhi memberikan penekanan toleransi ataupun penghormatan kepada agama lain tidak akan menggoyahkan atau melenyapkan keyakinan akan agama sendiri. Ia mencontohkan secara nyata studinya tentang agama Kristen, bahkan ia hendak mengatakan kepada orang-orang Hindu bahwa hidup tidak akan sempurna jika tidak mempelajari dengan penuh hormat ajaran-ajaran Yesus. Gandhi berkesimpulan bahwa siapapun, dari agama apapun, yang mempelajari dengan penuh hormat keyakinan-keyakinan lain, akan memperluas hati mereka, bukan sebaliknya. Gandhi secara khusus belajar banyak dari orang Kristen, bahkan ia menerima pengaruh Injil, terutama khotbah di bukit. Namun kedekatannya dengan orang-orang Kristen, kekagumannya kepada ajara Yesus, kecintaannya terhadap lagu-lagi Kristen, dan etika-etika Kristen tidak menggoyahkan atau menghilangkan keyakinannya, bahkan justru membawanya kepada keyakinannya yang lebih dalam kepada Hindu. Bentuk cinta Gandhi kepada Hindu diungkapkan dengan "bahasa kasih", dengan kesetiaan, terpusat, dan cinta yang memaafkan seperti yang diberikan kepada suami atau istri kita. Meskipun Gandhi memiliki pengalaman yang pahit tentang pandangan para misionaris Kristen di Rajkot, itu tidak melunturkan penghormatannya terhadap agama Kristen, bahkan ia mengagumi ajaran-ajaran Yesus dan etika-etika Kristen. Demikian pula kritikannya tentang penindasan terhadap Candala yang diangapnya sebagai penyimpangan terkutuk dari kebenaran agama, tidak membuat keyakinannya kepada agama Hindu luntur. Penghormatan terhadap tradisi atau agama lain tidaklah membuat keyakinan akan agama kita menghilang, namun apa yang dikhawatirkan oleh masyarakat luas adalah terjadinya proselitasi dan konversi. Gandhi menentang kedua hal itu. Menurutnya, proselitasi itu untuk mengalihkan orang-orang Hindu menjadi Kristen, ataupun meyakinkan orang lain untuk beralih dari satu agama ke agama lain adalah sebuah kejahatan dan tidak menguntungkan, terlebih lagi ada unsur pemaksaan. Itu didasari oleh teologi yang lemah dan miskin. Kemudian terkait konversi, ia mengatakan itu adalah urusan Tuhan, bukan urusan manusia. Pandangan Gandhi tentang proselitasi maupun konversi tidak dapat dilepaskan dari adanya pengaruh politik terhadap bentuk-bentuk proselitasi dan koversi tersebut di India. Misionaris Kristen datang bersama penjajah Inggris yang bersifat menindas. Sebelumnya, rangkaian penjajahan kerajaan Muslim di India membawa serta misi Islam, dan pada tahun 1920, gerakan orang- 
orang Hindu yang dipelopori Arya Samaj untuk mengalihkan kembali atau mensucikan (Suddhi) mereka yang sebelumnya selama berabad-abad telah dialihkan ke agama Islam. Gandhi menentang semua bentuk konversi agama, baik itu suddhi oleh orang Hindu, Tabligh oleh orang Islam, atau proselitasi oleh orang Kristen. Konversi menurut Gandhi adalah proses hati, dan hanya Tuhan yang tau. Suatu hal yang tidak masuk akal jika ada orang yang mengatakan bahwa seseorang akan menjadi baik atau memperoleh keselamatan hanya dengan memeluk satu agama tertentu, misal Hindu, Kristen, atau Islam. Demikian menurut pendapat Gandhi, dan ia menekankan bahwa konversi yang susungguhnya adalah seseorang Kristen atau Islam menjadi orang Kristen dan Islam yang lebih baik lagi dari sebelumnya, bukan perpindahan agama, melainkan meningkatkan keyakinan pada agama yang dianut. Namun, Gandhi memandang satu hal positif dari konversi yakni dalam perjuangan satyagrahanya yang bertujuan untuk mengkonversi lawan, bukan untuk mengalahkan mereka. Konversi dalam artian ini dimaksudkan merubah lawan menjadi kawan. Dalam perjumpaannya dengan orang-orang yang memiliki perbedaan pandangan maupun keyakinan dan tradisi agama yang berbeda, ia menginginkan suatu bentuk hubungan saling percaya, dari permusuhan menjadi persahabatan, bukan untuk mengalihkan satu pihak ke dalam doktrin-doktrin baru.

Hal penting lainnya dari prinsip-prinsip religius Gandhi adalah pernyataannya bahwa agama bukanlah untuk memisahkan manusia satu sama lain, melainkan agama adalah untuk mempersatukan mereka. Dewasa ini pemahaman itu sudah mengalami pergeseran nilai, dimana agama dijadikan sebagai kedok atau tameng untuk menghancurkan pihak atau agama minoritas, untuk menyebarluaskan agama melalui kekerasan, pertikaian, dan sebagainya. Gandhi memandang manusia sama, demikian pula tradisi agama memiliki kebenaran namun semuanya juga tidak sempurna. Jika berbicara soal gaya kepemimpinan Gandhi, maka kita sampai pada kesepakatan bahwa dalam kepemimpinannya, selalu didasarkan kepada prinsip-prinsip inklusif (menyertakan pihak lain). Dalam asrama yang ia bangun, terlihat jelas bagaimana ia merangkul semua kalangan, lelaki, perempuan, tua, muda, umat Muslim, Hindu, Kristen, Jahudi, Brahmin, dan kaum Candala. Asramanya adalah rumah tanpa jendela, tanpa pembatas, selalu terbuka untuk siapa saja yang memiliki keinginan baik, tanpa membeda-bedakan kasta, ras, jenis kelamin, agama, golongan, dan sebagainya. Hal itu tidak dapat dilepaskan dari prinsip-prinsip atau ajaran dan nilai-nilai kemanusiaan yang diterapkan Gandhi ke dalam peraturan hidup (etika) di asrama.

Terdapat 11 butir peraturan hidup yang dapat di ashram yang didirikan Gandhi yang patut diteladani yakni: 1) Sat (Kebenaran) yang melingkupi kebenaran pikiran, perkataan dan perbuatan; 2) Ahimsa (kasih sayang, tidak menyakiti baik pikiran, perkataan, dan perbuatan);3)Brahmacarya yang menekankan pengendalian nafsu hewani dan penguasaan setiap indra yang terdapat dalam diri manusia untuk mencapai kebenaran; 4) Penguasaan rasa lidah berkaitan dengan Brahmacarya, tidak menjadikan makan sebagai tujuan melainkan hanya sebatas sarana, tidak makan daging dan alkogol yang dapat memicu nafasu; 5) Asteya (tidak mencuri); 6) Aparigraha (memilih hidup dalam kesederhanaan; 7) Karya pangan merupakan upaya untuk memenuhi sikap hidup yang mengutamakan asteya dan aparigraha, usaha memenuhi kebutuhan hidup sendiri secara mandiri tanap melakukan pencurian; 8) Swadesi yang digambarkan sebagai bentuk pengorbanan diri kepada keluarga, pengorbanan keluarga untuk desa, desa untuk negara, dan negara untuk kemanusiaan, kemanusiaan menjadi inti semua bentuk pengabdian; 9) Nirbaya diartikan sebagai sikat yang tidak mengenal 
rasa takut terhadap kekuatan apapun, kecuali Tuhan, tidak takut berbicara di depan umum untuk memperjuangkan keadilan; 10) Menghapuskan rasa emoh bersentuhan yang pada dasarnya ingin menghapuskan kelaskelas sosial dalam masyarakat Hindu di India, karena di India terjadi proses pengeleminasian terhadap kelas-kelas sosial tertentu yang berdasarkan keturuan dan kelahiran (kasta), dimana kasta yang lebih tinggi seakan lebih mulia daripada kasta yang lebih rendah, sehingga mereka dilarang bersentuhan; 11) Toleransi menjadi prinsip yang amat penting, dimana dalam masyarakat yang heterogen harus menerapkan sikap toleransi, tidak membeda-bedakan suku, ras, agama, golongan, dan sebagainya.

Gandhi memandang bahwa semua agama yang ada mengandung wahyu Kebenaran, namun karena agama-agama tersebut garis besarnya dibuat oleh manusia yang tidak sempurna, maka keyakinan-keyakinan itu dipengaruhi oleh ketidaksempurnaan tersebut dan kebenaran tersebut menjadi tidak mutlak adanya. Membangkitkan semangat toleransi, ataupun penghormatan terhadap agama lain akan melahirkan pemahaman yang lebih mendalam terhadap agama kita sendiri, bukan sebaliknya meruntuhkan keyakinan akan agama yang kita anut. Inilah bentuk universalitas Gandhi. Menurutnya, sekatsekat atau pembatas yang diciptakan oleh agama-agama bertentangan dengan ajaran agama. Hal itu akan berimbas kepada munculnya sikap Pseudo Speciation, dimana adanya kecenderungan manusia untuk mengidentifikasikan diri mereka dengan membentuk kelompok-kelompok artifisial seperti kasta, golongan, dan sebagainya. Religio berarti mengikat, akan tetapi jika yang diikat bersama oleh agama hanyalah orangorang dari agama tersebut, maka sangat mudah bagi kekeluargaan agama itu untuk menjadi chauvinisme komunal (Madrasuta, 2002: 118). Gandhi berpandangan bahwa kekuatan kekeluargaan agama itu tidak harus bahkan tidak cukup untuk berhenti pada batas-batas keagamaan saja, namun terpenting adalah bagaimana mereka mampu memberikan perhatian, kasih sayang dan uluran tangan kepada orang lain yang memerlukan. Gandhi membuktikan hal itu ketika terjadi pemisahan antara India dan Pakistan. Ia menginginkan penyatuan dan perdamaian antara kedua pihak yakni kaum Muslim dan Hindu, dan ia membuktikan kepada kaum Muslim bahwa ia menyayangi mereka sebagaimana ia mengasihi orang-orang Hindu. Universalitas Gandhi itulah yang pada akhirnya merenggut nyawanya karena seorang ekstrimis Hindu yang kecewa dan merasa dikhianati oleh Gandhi yang membela kaum Muslim.

Gandhi memang memiliki ketertarikan kepada ajaran-ajaran dalam agama lain seperti khotbah Yesus di bukit yang memberinya inspirasi untuk menebar kasih kepada musuh sekalipun. Pandangan Gandhi terhadap khotbah tersebut telah memberikan kontribusi bagi umat Kristen dan mengungkap kenyataan bahwa tidak sedikit misisionaris Kristen yang melakukan kekerasan, peperangan atas nama agama. Gandhi menolak keras gagasan teologia Kristen yang menyatakan bahwa kebenaran hanya bisa dicapai melalui agama Kristen. Ia menolak dogma-dogma Kristen, walaupun ia juga memiliki pandangan positif terhadap ajaran kasih sayang Yesus, namun keyakinannya terhadap agama Hindu tidak pernah luntur sedikitpun. Semenjak ketekunan Gandhi menelususi kitab suci maupun teks-teks Kristen, muncul beragam pembaharuan dalam hal konsep dialog antar umat beragama. Melalui dialog ini, umat Kristen mulai memiliki pandangan baru dan pemikiran yang luas tentang agama Kristen, terkait budaya yang telah dibentuk melalui sejarah Kristen. Perjuangan Gandhi dengan mengkampanyekan dialog lintas agama ini menimbulkan banyak simpati dari umat Kristen, selain juga banyak kritikan yang dilontarkan kaum anti gagasan Gandhi tersebut. Berdasarkan penelusuran Gandhi 
terhadap teks-teks Kristen, menghasilkan beberapa keseimpukan bahwa semua agamaitu benar, namun meskipun benar, semua agama juga memiliki kelemahan dan kesalahan di dalam prakteknya, dan semua agama memiliki kedudukan yang sama dalam hal penghormatan dan saling menghargai antar sesama manusia, layaknya saudara sendiri, toleransi dan kasih sayang ditonjolkan sebagai bentuk praktek keagamaan yang sesungguhnya. Gandhi memang secara tegas mengatakan bahwa ia mempelajari Injil dan kitab agama dunia lainnya, dan bahkan ketika ia bertugas di Afrika Selatan, ia menjadi target konversi orang-orang Kristen disana, namun hal itu tidak serta merta merubah keyakinannya untuk memeluk agama Kristen, tetapi justru semakin meningkatkan keyakinannya kepada agama Hindu yang dianut.

Gandhi menentang keras kasus konversi yang terjadi di India. Ia berpandangan bahwa koversi maupun proselitasi adalah tindakan yang jahat, memaksa seseorang dari umat Hindu dengan jalan kekerasan untuk meyakini doktrin baru agama Kristen misalnya adalah tidak benar. Berdasarkan tinjauan historis, agama Hindu sejak berabad-abad selalu menjadi target konversi. Disamping menjadi target konversi, Hindu juga menjadi sasaran empuk berbagai tuduhan dan prasangka miring yang penuh penghinaan. Meskipun demikian, orang-orang Hindu bebas dari doktrin bahwa agama Hindu adalah agama yang paling benar di mata Tuhan, dan menjanjikan orang yang memeluk agama Hindu dipastikan masuk surga dan sebagainya seperti doktrin dalam Kristen dan Islam. Hindu dikatakan penyembah berhala dan kaum kafir. Di tengah gempuran dan tuduhan miring tersebut, pada abad ke 18 muncul pertama kalinya ada orang Hindu yang memberikan perlawanan yaitu Swami Dayananda Saraswati pendiri gerakan reformasi Hindu, Arya Samaj. Untuk menangkis serangan teologis dari agamaagama lain, ia mempelajari Bible dan Qur'an secara teliti dan memberikan kritik yang tajam terhadap kedua kitab suci itu. Ia sampai pada kesimpulan bahwa Veda adalah mata pancuran dari ilmu pengetahuan dan agama, bahwa semua agama dunia, termasuk Islam dan Kristen, hanyalah bidah atau penyimpangan yang membingungkan dari Veda. Demikian pula Gandhi yang melakukan dialog dengan para missionaris Kristen di India yang ingin mengkristentkan dirinya dan orang-orang Hindu lainnya. Di dalam proses itu, ia juga memberikan kritiknya terhadap kekristenan, baik yang menyangkut prilaku maupun dogma agama Kristen (Knapp dkk, 2005: vii-viii).

Kita tentu sudah mengenal mahavakya Sarva Dharma Samabhava (semua agama sama), namun semua agama juga memiliki kelemahan dan tidak sempurna seperti yang pernah dilontarkan Gandhi. David Frawley (dalam Knapp dkk, 2005: ix) membantah pernyataan semua agama sama saja. Ia berpandangan bahwa ada agama yang berdasarkan dogma, kepercayaan irasional yang harus diterima begitu saja, dan ada agama yang berdasarkan dharma, hukum universal, yang dapat diperiksa dan diuji oleh akal. Agama-agama dogmatik bersifat ekslusif, merasa memonopoli kebenaran, mempunyai kecenderungan untuk menaklukkan, menguasai dan mengendalikan serta sering menganjurkan kebencian, kekerasan terhadap orang-orang beragama lain. Sedangkan agama yang berdasarkan dharma tidak memiliki ambisi untuk menaklukkan dan menguasai, karena tujuan agama bukan untuk menjadi imperialisme politik dan budaya, tapi untuk memberikan kesadaran diri atau pencerahan spiritual kepada setiap orang. Agama-agama ini dapat menerima kebenaran darimanapun datangnya. Ia bersifat terbuka dan toleran. Itulah agama universal yang sesungguhnya. Pernyataan itu sejalan dengan pemikiran Gandhi, dengan semangat universalitasnya, dimana agama sesungguhnya diciptakan untuk mempersatukan manusia, bukan untuk memisahkannya. Semua agama mengajarkan kebenaran, namun semua agama juga tidak 
sempurna. Jika semua orang dari tradisi agama yang berbeda memiliki pandangan yang serupa, tentu tujuan agama untuk mempersatukan manusia akan terwujud. Namun nampaknya hal itu sulit untuk diwujudkan dewasa ini, dimana setiap orang hendaknya bersikap hormat kepada agama lainnya, mempelajari kitab suci agama lain, bukan untuk memeluk agama tersebut, namun untuk menigkatkan keyakinan kita kepada agama yang kita anut. Pandangan Gandhi tentang konversi nampaknya sulit untuk ditanamkan di benak umat beragama dewasa ini. Di Indonesia sendiri, berbagai kasus konversi mewarnai kehidupan umat, seperti misalnya di tahun 2002, ada 92 warga Tengger beralih dari agama Hindu ke agama Islam, kemudian di tahun yang sama, sebanyak 134 KK di Klecung, Selemadeg, Tabanan resmi keluar dari agama Hindu untuk memeluk agama lain.

Mereka memiliki berbagai alasan tapi secara umum mereka kurang memahami ajaran Hindu apalagi kitab sucinya. Mereka mewarisi ajaran Hindu dari leluhurnya secara gugon tuwon, selain itu juga karena mereka hidup dalam kemiskinan, sehingga menyulitkan mereka ketika melaksanakan upacara agama (Sargede, 2005: 39-49). Selain kasus konversi, konflik-konflik antarumat juga kerap mewarnai kehidupan beragama di tanah air. Fanatisme terhadap ajaran agama telah membutakan semangat toleransi yang menjadi bagian dari semboyan negara ini. konflik bernuansa SARA yang terjadi pada beberapa daerah di tanah air hingga menimbulkan kerugian material dan banyaknya korban jiwa, merupakan cerminan kurangnya pemahaman umat akan keberagaman budaya, agama, dan tradisi di tanah air. Sejarah pada dasarnya menuntun kita untuk selalu bercermin pada masa lalu, dimana hal-hal baik yang terjadi dapat diteladani, dan demikian sebaliknya hal buruk yang terjadi patutnya dihindari dan dijadikan peringatan untuk tidak mengulangi kembali. Sejarah India bahkan dunia mencatat perjuangan Gandhi dalam merebut kemerdekaan India tidak lepas dari prinsipprinsip yang dipegang teguh. Ajaran ahimsa yang lebih dikenal dengan istilah nir-kekerasan atau tanpa kekerasan merupakan salah satu prinsip Gandhi yang menjadikannya pribadi humanis penuh kasih sayang. Ia tidak pernah menggunakan kekerasan dalam hal apapun. Sikap pantang kekerasan menurutnya bukanlah sikap penghindaran dari perkelahian melawan kejahatan, melainkan sebaliknya sikap pantang kekerasan merupakan perkelahian yang lebih aktif dan lebih nyata melawan kejahatan, dibanding dengan pembalasan dendam yang hanya menambah kejahatan itu sendiri. Dengan upaya itu, Gandhi telah menumpulkan mata pedang para penindas dengan mengecewakan harapan-harapan para penindas akan balasan perlawanan secara fisik. Ia selalu mengedepankan kepentingan kemanusiaan secara lebih luas daripada melakukan perlawanan dengan jatuhnya korban-korban manusia.

Kemerdekaan India tidak lepas dari peran Gandhi yang menjalankan aksi perlawanannya tanpa kekerasan, selalu mengedepankan nilai-nilai kemanusian melalui gerakan ahimsa (tidak membunuh, tidak menyakiti, tidak membenci), satyagraha (berpegang teguh pada kebenaran atau mengejar tujuan yang benar dengan sarana ahimsa), swadesi (mencintai tanah air sendiri), dan hartal (pemogokan nasional). Ketika India berhasil merebut kemerdekaannya pada tanggal 15 Agustus 1947, itu sekaligus merupakan akhir dari perselisihan antara India dan Inggris selama puluhan tahun, dan seluruh rakyat India berbahagia, kecuali Gandhi. Ia merasakan bahwa kemerdekaan sesungguhnya belum diraih, karena idaman Gandhi adalah kesatuan, kesatuan yang telah ia perjuangkan seumur hidupnya. Ia merasa ditinggalkan teman serta kolega tercintanya (Nicholson dalam Wisarja, 2007: 51). Hal itu berakar dari adanya pemisahan dua wilayah penting dengan mayoritas kaum Muslim di 
India yang tidak dapat dibendung lagi yakni Bengal di timur dan Punyab di Barat menjadi wilayah sendiri yaitu Pakistan. Gandhi tidak menginginkan pemisahan itu, dan meskipun India sudah merdeka, namun Gandhi masih terus berjuang untuk menyelesaikan konflik antara komunitas Hindu dan Muslim. Ia merasa belum menemukan kebahagiaan karena pemisahan dan konflik itu. Namun, usahanya untuk menghentikan permasalahan itu justru menjadi penyebab kematiannya. Ia dibunuh oleh seorang militan bernama Natutam Godse yang merasa dikhianati karena Gandhi membela kaum Muslim. Pada saat kematiannya, Gandhi sempat berbisik "Hey Rama" (Oh Tuhan) lalu jatuh bersimbah darah (Wisarja, 2007: 51).

Perjuangan Gandhi hendaknya mampu meginspirasi bangsa ini. Jika saja prinsipprinsip Gandhi bisa kita adopsi, tentu konflikkonflik bernuansa SARA maupun kasus konversi agama dapat diantisipasi, terlebih prinsip-prinsip Gandhi sejalan dengan semboyan negara ini "Bhineka Tunggal Ika". Konflik bernuansa SARA yang terjadi di Indonesia atas dasar monopoli kebenaran oleh kelompok-kelompok tertentu telah membangun dinding pemisah bagi semangat toleransi. Kelompok-kelompok seperti FPI yang mengatasnamakan agama Islam tidak jarang menggunakan kekerasan dalam setiap aksinya. Merusak tempat-tempat hiburan ketika memasuki masa puasa umat Muslim dengan dalih tempat-tempat itu telah mengotori perayaan hari suci mereka. Menghujat umat lain karena tradisi agama yang berbeda. Terorisme yang berkedok memusnahkan kaum kafir, dengan jalan kekerasan dan pembunuhan, merupakan bukti rendahnya pemahaman mereka akan agama yang dianut. Ajaran agama telah terdistorsi, tidak lagi murni karena dipahami oleh manusia yang tidak memiliki kesempurnaan sehingga kebenaran ajaran agama menjadi sirna dan meyimpang. Ini bertentangan dengan ajaran Ahimsa, Satyagraha dan Swadesi yang dicetuskan
Gandhi. Ajaran Ahimsa tidak hanya diartikan sikap tidak membunuh atau tidak menyakiti, namun lebih dalam lagi bahwa dengan tidak memendam pikiran yang tidak baik dan buruk terhadap orang lain atau kelompok lain, tidak berkata-kata yang kasar terhadap orang lain merupakan bagian dari ajaran ahimsa Gandhi. Antara satyagraha dan ahimsa tidak dapat dipisahkan. Satyagraha mengajarkan manusia untuk selalu berpegang teguh pada kebenaran, dan untuk mencapai kebenaran hendaknya melalui sarana ahimsa (nir kekerasan). Untuk mewujudkan masyarakat yang humanis, tentu prinsip-prinsip Gandhi patut diteladani dan diaplikasikan.

\section{PENUTUP}

Gandhi percaya bahwa setiap agama mengandung wahyu kebenaran yang kemudian mengalami distorsi atau penyimpangan karena garis-garis besar ajarannya yang dibuat oleh manusia yang tidak sempurna, sehingga keyakinan-keyakinan itu dipengaruhi oleh ketidaksempurnaan tersebut dan kebenarannya menjadi tidak mutlak adanya. Hal itu tentu didasari oleh pengalamannya yang telah mempelajari kitab suci agama lain. Semangat toleransi yang ia tunjukkan tidaklah membuat keyakinannya kepada agama Hindu luntur, justru semakin kuat. Menurutnya, semua agama benar, namun semua agama tidak sempurna dan menjadi subjek kesalahan. Gandhi menentang segala bentuk konversi agama, dan ia memandang itu sebagai suatu bentuk kejahatan. Prinsip hidup Gandhi diyakini berlaku secara universal karena bertujuan mewujudkan kebenaran, kebaikan, keharmonisan, perdamaian, keselarasan dan sebagainya, terlebih ajarannya sama sekali tidak bertetangan dengan harkat dan martabat manusia. Ajaran Gandhi yang memperlakukan lawan atau musuh dengan kasih sayang dan tanpa kekerasan, telah meluluhkan hati mereka dan merubah sikap mereka menjadi lunak. Gandhi memberikan sumbangan besar bagi 
kehidupan sosial, budaya, politik, ekonomi melalui ajaran ahimsa atau nir kekerasan yang telah ia jalankan dan terbukti berhasil dalam upaya merebut kemerdekaan India. Ajaran itu akan berujung kepada munculnya rasa saling mengasihi, menghormati dan menghargai satu sama lain sehingga terwujud kehidupan yang harmonis.

Namun demikian, meskipun ajaran Gandhi berlaku universal, karakter Gandhi serta prinsip-prinsip dan ajarannya yang mengandungkebenaran dan didasarikebenaran tidak dapat merasuk ke dalam sanubari setiap manusia. Dalam artian, ajaran Gandhi tidak dapat dipahami dan diaplikasikan oleh semua umat manusia di dunia ini. Secara psikologis, ada orang yang memiliki karakter pendendam, keras kepala, ingin berkuasa atas orang lain, iri hati, dengki dan sifat buruk lainnya. Bagi mereka tentu ajaran Gandhi akan sulit untuk diterima, misalkan memafkan orang yang telah menyakiti dirinya atau bahkan mungkin telah membunuh anggota keluarganya.

Semua orang tentu sepakat bahwa tujuan Gandhi adalah untuk mendatangkan kebaikan bagi umat manusia, dan usahanya untuk menyelesaikan beragam konflik itulah yang membuat namanya dikenal masyarakat luas. Idealnya, konflik bersifat netral, artinya jika konflik dapat diselesaikan dengan baik, maka akan menimbulkan dampak positif bagi pihak yang berkonflik, demikian sebaliknya. Sejalan dengan pemikiran Karl Marx bahwa konflik dibuat sedemikian rupa agar masyarakat tetap dinamis dan berkembang. Konflik diartikan sebagai ancaman, tantangan, hambatan dan gangguan, sehingga dengan adanya konflik, manusia akan selalu mencari cara untuk menyelesaikannya. Dalam perjalanannya akan melahirkan pandangan dan pemikiran yang baru layaknya pemikiran-pemikiran Gandhi dalam upayanya menyelesaikan konflik. Di Indonesia sendiri, dengan masyarakatnya yang plural, ajaran Gandhi ini tentu cocok untuk diterapkan. Konflik antar umat beragama di negara ini yang cenderung menggunakan kekerasan dan mengarah kepada perpecahan bangsa, diharapkan dapat diantisipasi sejak dini dengan mengadopsi prinsip-prinsip Gandhi ini. Gandhi berpandangan bahwa semua agama pada dasarnya memiliki ajaran nir kekerasan yang sama serta toleransi yang tinggi, hanya saja hal itu mengalami penyimpangan akibat pemahaman dari manusia yang tidak sempurna dan penuh keterbatasan. Terlebih lagi semua ajaran Gandhi sejalan dengan nilai-nilai Pancasila dan semboyan negara Indonesia.

\section{DAFTAR PUSTAKA}

Knapp, Stephen. 2005. Hindu Agama Terbesar di Dunia (Hinduism, the Greatest Religion in the World). Media Hindu.

Koentjaraningrat. 2005. Pengantar Antropologi Pokok-pokok Etnografi II. Jakarta: Rineka Cipta.

Madrasuta, Ngakan Made dan Sang Ayu Putu Renny. 2002. Gandhi dalam Dialog Hindu-Kristen. Surabaya: Paramita.

Prabhu, R.K. 1996. Tuhanku (My God). Denpasar: Yayasan Bali Canti Sena.

Sargede. 2005. Kebangkitan Hindu dalam Kritik, Himpitan, Kesadaran, Kedamaian dan Kebahagiaan Rohani. Surabaya: Paramita.

Wisarja, I Ketut. 2007. Gandhi dan Masyarakat Tanpa Kekerasan. Surabaya: Paramitha. 